\title{
Metode Simple Multi Attribute rating Technique (SMART) Dalam Menentukan Penerima Dana Bantuan Yayasan AMIK Tunas Bangsa
}

\author{
Sundari Retno Andani \\ AMIK Tunas Bangsa Pematangsiantar \\ Jln. Jend. Sudirman Blok. A No. 1 Pematangsiantar \\ Sundari.ra@yahoo.co.id
}

\begin{abstract}
Foundation grants are funds that comes from foundation and given for student achievement and poor, which aims to prevent collage drop outs for students. The criteria used in determining the foundation grant recipients are GPA, parent's income and the number of dependents. The method applied in determining the foundation grant recipients is SMART (Simple Multi Attribute rating Technique) method. Because this method able to solve the multicriteria decision making problems, base on theory that each criteria has a weight that describes how important these criteria with other criteria. The results of this research are recommendations from recipients of foundation grant.
\end{abstract}

Keywords: Decision Support System, SMART

\begin{abstract}
Abstrak
Dana bantuan yayasan merupakan dana yang berasal dari yayasan dan diperuntukkan bagi mahasiswa berprestasi dan kurang mampu dari segi ekonomi, yang bertujuan agar tidak terjadi putus kuliah bagi mahasiswa. Kriteria yang digunakan dalam menentukan penerima dana bantuan yayasan adalah IPK, penghasilan orang tua dan jumlah tanggungan. Metode yang diterapkan dalam menentukan penerima dana bantuan yayasan AMIK Tunas Bangsa Pematangsiantar adalah metode SMART (Simple Multi Attribute rating Technique), karena metode ini mampu menyelesaikan masalah pengambilan keputusan multikriteria, berdasarkan teori bahwa setiap alternatif terdiri dari sejumlah kriteria yang memiliki nilai-nilai dan setiap kriteria memiliki bobot yang menggambarkan seberapa penting kriteria tersebut dengan kriteria lain. Hasil dari penelitian ini adalah rekomendasi penerima dana bantuan yayasan.
\end{abstract}

Kata kunci: Sistem Pendukung Keputusan, SMART

\section{PENDAHULUAN}

Dana bantuan merupakan pemberian bantuan kepada perorangan berupa dana yang digunakan untuk keberlangsungan pendidikan. Bantuan dana yayasan AMIK Tunas Bangsa diberikan kepada mahasiswa berprestasi dan kurang mampu dari segi ekonomi. Penentuan penerima bantuan dana dilakukan secara selektif, namun belum menerapkan sistem pendukung keputusan. Sehingga output yang dihasilkan kurang akurat. Menurut [1] sistem pendukung keputusan merupakan sistem yang memiliki kemampuan pemecahan masalah dan kemampuan pengkomunikasian untuk masalah dengan kondisi semi terstruktur dan tak terstruktur. Menurut Turban [2] bahwa sistem pendukung keputusan merupakan penggabungan kemampuan komputer dalam pelayanan interaktif dengan pengolahan atau pemanipulasi 
data yang memanfaatkan model atau aturan penyelesaian yang tidak terstruktur.

Pada penelitian ini, penulis menggunakan metode SMART untuk memberikan rekomendasi penerima beasiswa yayasan AMIK Tunas Bangsa. Menurut [3], ada beberapa kriteria yang digunakan dalam pengambilan keputusan penerima beasiswa yayasan, yaitu IPK, penghasilan orang tua dan jumlah tanggungan orang tua. Menurut [4] bahwa metode SMART dapat melakukan pengambilan keputusan yang multiatribut. Metode pembobotan SMART merupakan metode pendukung keputusan yang paling sederhana, hal ini sesuai dengan pernyataan [5] dalam penelitiannya. Pada penelitian sebelumnya, SMART banyak diteliti oleh peneliti-peneliti diantaranya [6], [7], [8], [9], [12], [13], [14] dan [15]. Selain lebih sederhana, pada metode SMART, penambahan dan pengurangan alternatif tidak akan mempengaruhi perhitungan pembobotan, karena setiap penilaian alternatif tidak saling bergantung.

\section{METODOLOGI PENELITIAN}

Metodologi penelitian merupakan sistematika tahapan yang dilaksanakan selama penelitian. Pada penelitian ini, ada lima proses tahapan yang akan diselesaikan yaitu Pengumpulan data, Analisa Sistem, dan desain sistem.

a. Pengumpulan data

Pada tahap ini dilakukan pengumpulan data mahasiswa. Data mahasiswa diperolah dari bagian pendidikan AMIK Tunas Bangsa Pematangsiantar.

b. Analisa Sistem

1) Analisa sistem lama

Pada tahap ini dilakukan analisa dalam seleksi penerima beasiswa yayasan AMIK Tunas Bangsa. Pada AMIK Tunas Bangsa dalam menentukan penerima beasiswa masih menggunakan sistem manual.

2) Analisa sistem baru

Analisa sitem dilakukan untuk menyusun langkah demi langkah penguraian dari sebuah sistem informasi yang nantinya akan dirancang/dikembangkan dengan maksud mencari atau mengidentifikasi dan mengevaluasi permasalahan-permasalahan yang akan terjadi pada sistem yang akan dirancang. Serta kebutuhankebutuhan apa saja yang diinginkan untuk mengatasi/menangani permasalahan yang ada pada pengguna sistem nantinya. Jika terdapat satu proses saja yang terjadi penyimpangan atau kesalahan maka untuk proses berikutnya juga akan terjadi kesalahan karena prosesproses tersebut selalu berhubungan.

c. Desain Sistem

Pada tahap ini dilakukan desain sistem pendukung keputusan Dalam menentukan penerima dengan metode SMART. 


\section{HASIL DAN PEMBAHASAN}

Data sample yang digunakan pada penelitian ini adalah data mahasiswa AMIK Tunas Bangsa Pematangsiantar sebanyak 10 orang. Berikut sample data mahasiswa :

Tabel 1. Data Mahasiswa

\begin{tabular}{|c|c|l|c|c|c|}
\hline NO & \multicolumn{1}{|c|}{ NIM } & \multicolumn{1}{|c|}{ Nama } & IPK & $\begin{array}{c}\text { Pendapatan } \\
\text { Orang Tua }\end{array}$ & $\begin{array}{c}\text { Jlh } \\
\text { Tanggungan }\end{array}$ \\
\hline 1 & 201701030082 & $\begin{array}{l}\text { ABDULLAH } \\
\text { AHMAD }\end{array}$ & 3.91 & 3.5 & 4 \\
\hline 2 & 201701030096 & $\begin{array}{l}\text { DYAH AYU } \\
\text { SAFITRI }\end{array}$ & 3.73 & 3 & 3 \\
\hline 3 & 201701030031 & SRI WULANDIKA & 3.68 & 2 & 2 \\
\hline 4 & 201701030050 & $\begin{array}{l}\text { FRENDY SISKO } \\
\text { SIMBOLON }\end{array}$ & 3.64 & 2 & 3 \\
\hline 5 & 201701030041 & ALVIN SIJABAT & 3.59 & 2 & 3 \\
\hline 6 & 201701030065 & $\begin{array}{l}\text { NURANNISA } \\
\text { PULUNGAN }\end{array}$ & 3.55 & 2.5 & 2 \\
\hline 7 & 201701030026 & $\begin{array}{l}\text { PIPIT MUTIARA } \\
\text { DEWI }\end{array}$ & 3.55 & 2.7 & 2 \\
\hline 8 & 201701030027 & RIKA ASMA DEWI & 3.55 & 1.2 & 2 \\
\hline 9 & 201701030008 & DEVI MONIKA & 3.55 & 1.3 & 3 \\
\hline 10 & 201701030013 & $\begin{array}{l}\text { ENJELICA } \\
\text { RUMAPEA }\end{array}$ & 3.5 & 2.3 & 2 \\
\hline
\end{tabular}

\subsection{Menentukan Kriteria}

Pada penelitian ini, penulis menggunakan tiga kriteria, yaitu IPK, Pendapatan Orang Tua dan Jumlah Tanggungan.

Tabel 2. Data Mahasiswa

\begin{tabular}{|c|c|c|}
\hline IPK & Nilai & \multirow{2}{*}{ Bobot } \\
\hline$>=3.75$ & 100 & \\
\hline $3.5-3.74$ & 80 & \\
\hline $3.25-3.49$ & 60 & \multirow{2}{*}{$40 \%$} \\
\hline $3-3.24$ & 40 & \\
\hline$<3$ & 20 & \\
\hline
\end{tabular}

Tabel 3. Pendapatan Orang Tua

\begin{tabular}{|c|c|c|}
\hline $\begin{array}{c}\text { Pendapatan Orang } \\
\text { Tua }\end{array}$ & Nilai & Bobot \\
\hline$<=1.500 .000$ & 100 & \multirow{2}{*}{$30 \%$} \\
\hline $1.500 .001-2.500 .000$ & 80 & \multirow{2}{*}{300} \\
\hline $2.500 .001-3.500 .000$ & 60 & \\
\hline $3.500 .001-4.500 .000$ & 40 & \\
\hline$>4.500 .000$ & 20 & \\
\hline
\end{tabular}


Tabel 4. Jumlah Tanggungan

\begin{tabular}{|c|c|c|}
\hline Jumlah Tanggungan & Nilai & \multirow{2}{*}{ Bobot } \\
\hline$y=5$ & 100 & \multirow{1}{*}{$30 \%$} \\
\cline { 1 - 2 } 4 & 80 & \multirow{2}{*}{$30 \%$} \\
\hline 3 & 60 & \\
\hline 2 & 40 & \\
\hline 1 & 20 & \\
\hline
\end{tabular}

\subsection{Normalisasi}

Berikut adalah normalisasi data kriteria berdasarkan bobot yang telah ditentukan oleh peneliti seperti yang ditunjukkan pada tabel berikut:

Tabel 5. Normalisasi Data

\begin{tabular}{|c|c|c|}
\hline Kriteria & Bobot & Normalisasi \\
\hline IPK & $40 \%$ & 0,4 \\
\hline Pendapatan Orang Tua & $30 \%$ & 0,3 \\
\hline Jumlah Tanggungan & $30 \%$ & 0,3 \\
\hline
\end{tabular}

\subsection{Menentukan Nilai Utility}

Berikut nilai utility

$$
\begin{array}{ll}
\mathrm{C}_{\max }=5 & =100 \cdot(5-1) /(5-1) \\
\mathrm{C}_{\min }=1 & =100
\end{array}
$$

\subsection{Menentukan Nilai Akhir}

Berikut hasil nilai akhir dari sample yang telah ditentukan:

1. Abdullah Ahmad :

$$
\begin{aligned}
& C 1=100 \\
& C 2=60 \\
& C 3=80 \\
& =(100 * 0,4)+(60 * 0.3)+(80 * 0.3) \\
& =40+18+24 \\
& =82
\end{aligned}
$$

2. Dyah Ayu Safitri

$$
\begin{aligned}
& \mathrm{C} 1=80 \\
& \mathrm{C} 2=40 \\
& \mathrm{C} 3=60 \\
& =(80 * 0,4)+(40 * 0.3)+(60 * 0.3) \\
& =32+12+18 \\
& =62
\end{aligned}
$$

3. Sri Wulandika

$$
\begin{aligned}
& \mathrm{C} 1=80 \\
& \mathrm{C} 2=80 \\
& \mathrm{C} 3=40
\end{aligned}
$$




$$
\begin{aligned}
& =(80 * 0,4)+(80 * 0.3)+(40 * 0.3) \\
& =32+24+12 \\
& =68
\end{aligned}
$$

4. Frendy Sisko Simbolon

$$
\begin{aligned}
\mathrm{C} 1 & =80 \\
\mathrm{C} 2 & =80 \\
\mathrm{C} 3 & =60 \\
& =(80 * 0,4)+(80 * 0.3)+(60 * 0.3) \\
& =32+24+18 \\
& =74
\end{aligned}
$$

5. Alvin Sijabat

$$
\begin{aligned}
C 1 & =80 \\
C 2 & =80 \\
C 3 & =60 \\
= & (80 * 0,4)+(80 * 0.3)+(60 * 0.3) \\
= & 32+24+18 \\
= & 74
\end{aligned}
$$

6. Nurannisa Pulungan

$$
\begin{aligned}
\text { C1 } & =80 \\
\text { C2 } & =80 \\
\text { C } 3 & =40 \\
= & (80 * 0,4)+(80 * 0.3)+(40 * 0.3) \\
= & 32+24+12 \\
= & 68
\end{aligned}
$$

7. Pipit Mutiara Dewi

$$
\begin{aligned}
\text { C1 } & =80 \\
\text { C2 } & =60 \\
\text { C } 3 & =40 \\
= & (80 * 0,4)+(60 * 0.3)+(40 * 0.3) \\
= & 32+18+12 \\
= & 62
\end{aligned}
$$

8. Rika Asma Dewi

$$
\begin{aligned}
\text { C1 } & =80 \\
\text { C2 } & =100 \\
\text { C } 3 & =40 \\
= & (80 * 0,4)+(100 * 0.3)+(40 * 0.3) \\
= & 32+30+12 \\
= & 74
\end{aligned}
$$

9. Devi Monika 


$$
\begin{aligned}
C 1 & =80 \\
C 2 & =100 \\
C 3 & =40 \\
= & (80 * 0,4)+(100 * 0.3)+(40 * 0.3) \\
= & 32+30+12 \\
= & 74
\end{aligned}
$$

10. Enjelica Rumapea

$$
\begin{aligned}
& \text { C1 }=80 \\
& \text { C2 }=80 \\
& \text { C3 }=60 \\
& =(80 * 0,4)+(80 * 0.3)+(60 * 0.3) \\
& =32+24+18 \\
& =74
\end{aligned}
$$

Berikut hasil dari perhitungan nilai akhir dengan menggunakan metode SMART (Simple Multi Attribute rating Technique) sehingga diperoleh ranking tertinggi sampai terendah dari calon penerima beasiswa.

Tabel 6. Hasil Akhir Perangkingan

\begin{tabular}{|c|c|l|c|c|}
\hline No & NIM & \multicolumn{1}{|c|}{ Nama } & $\begin{array}{c}\text { Nilai } \\
\text { Akhir }\end{array}$ & Ranking \\
\hline 1 & 201701030082 & ABDULLAH AHMAD & 82 & 1 \\
\hline 2 & 201701030096 & DYAH AYU SAFITRI & 62 & 9 \\
\hline 3 & 201701030031 & SRI WULANDIKA & 68 & 7 \\
\hline 4 & 201701030050 & FRENDY SISKO SIMBOLON & 74 & 2 \\
\hline 5 & 201701030041 & ALVIN SIJABAT & 74 & 3 \\
\hline 6 & 201701030065 & NURANNISA PULUNGAN & 68 & 8 \\
\hline 7 & 201701030026 & PIPIT MUTIARA DEWI & 62 & 10 \\
\hline 8 & 201701030027 & RIKA ASMA DEWI & 74 & 4 \\
\hline 9 & 201701030008 & DEVI MONIKA & 74 & 5 \\
\hline 10 & 201701030013 & ENJELICA RUMAPEA & 74 & 6 \\
\hline
\end{tabular}

\section{SIMPULAN}

Adapun kesimpulan dari penelitian ini adalah :

a. Metode SMART dapat melakukan pengambilan keputusan yang multiatribut.

b. Metode pembobotan SMART merupakan metode pendukung keputusan yang paling sederhana.

c. Selain lebih sederhana, pada metode SMART, penambarahan dan pengurangan alternatif tidak akan mempengaruhi perhitungan pembobotan, karena setiap penilaian alternatif tidak saling bergantung. 
Jurnal Sains Komputer \& Informatika (J-SAKTI)

Volume 3 Nomor 2 September 2019, pp. 160-166

ISSN:2548-9771/EISSN:2549-7200

http://tunasbangsa.ac.id/ejurnal/index.php/jsakti

\section{DAFTAR PUSTAKA}

[1] I.M.A. Santosa, Perancangan Sistem Pendukung Keputusan Pemilihan Sekolah PAUD Menggunakan Metode SMART, Konferensi Nasional Sistem \& Informatika, 441-451, 2017.

[2] E. Turban. \& J.E. Aronson, Decision Support System and Intelligent System, 6th Edition, Prentice Hall Inc., New Jersey, 2001.

[3] S.R. Andani \& S. Wibowo, Sistem Pendukung Keputusan Dalam Menentukan Penerima Beasiswa Dengan Fuzzy Sugeno, TECHSI : Vol. 10 No.1, 2018.

[4] Y. Kustiyahningsih \& N. Syafa'ah, Sistem Pendukung Keputusan Untuk Menentukan Jurusan Pada Siswa SMA Menggunakan Metode KNN dan SMART, Jurnal Sistem Informasi Indonesia Vol.1 No.1, 2015.

[5] E. Yulianti, Sistem Pendukung Keputusan Pemilihan Mobil Dengan Metode Simple Multy Attribute Rating (SMART), Jurnal Momentum Vol. 17 No. 1, 2015.

[6] Suryanto \& M. Safrizal, Sistem pendukung Keputusan Pemilihan Karyawan Teladan Dengan Metode SMART (Simple Multi Attribute Rating Technique), Jurnal CoreIT Vol.1 No. 2, 2015.

[7] Nurhasanah, Pendukung Keputusan Penentuan Penerima Beasiswa Menggunakan Metode SMART (Simple Multi Attribute Rating Technique), Majalah Ilmiah INTI Vol. XII No. 1, 2017.

[8] D. Novianti, I. F. Astuti \& D. M. Khiarina, Sistem Pendukung Keputusan Berbasis Web Untuk Pemilihan Cafe Menggunakan Metode SMART (Simple Multi Attribute Rating Technique), Prosiding Seminar Sains dan Teknologi FMIPA Unmul, 2016.

[9] R. Yunitarini, Sistem Pendukung Keputusan Pemilihan Penyiar Radio Terbaik, Jurnal Ilmiah Mikrotek Vol. 1 No. 1, 2013.

[10] P. Goodwin \& G. Wright, Decision Analysis For Management, Judgment 3rd Edition, Newyork : John Wiley \& Sons, 2004.

[11] A. Kadir, Pengenalan Teknologi Informasi, 2003.

[12] M. Situmeang, Perancangan Aplikasi Penilaian Hasil Kinerja Dosen Terbaik Dengan Metode Simple Multi Attribute Rating Technique Studi Kasus : AKPER Yayasan Binalita SudamaMedan, Jurnal Ilmiah Pelita Informatika Budi Darma Vol. IX No. 1, 2015.

[13] H.D. Budiman, Sistem Pendukung Keputusan Anggota Kepolisian Terhadap Calon Seleksi Alih Golongan Menggunakan Metode SMART, http://repository.upi.edu/, 2013.

[14] P. Wulandari, Sistem Pendukung Pengambilan Keputusan Pemilihan Ponsel Dengan Metode SMART, http://digilib.ittelkom.ac.id/index.php?option=com_repository\&Itemid=34\&tas $\mathrm{k}=$ detail\&nim=613041006, 2007.

[15] F.M. Kasie, Combining Simple Multiple Attribute Rating Technique and Analytical Hierarchy Process for Designing Multi-CriteriaPerformanceMeasurement Framework, Global Journal of Researches in Engineering Industrial Engineering Vol. 13 Issue 1 Version 1.0, Global Journal Inc, USA, 2013. 